\title{
Seasonal Variation of Energy Sources in the Earth Surface Layer and in the Atmosphere over the Northern Hemisphere
}

\author{
By Isao Kubota \\ Japan Meteorological Agency, Tokyo \\ (Manuscript received 2 February 1968, in revised form 9 October 1969)
}

\begin{abstract}
Climatic energy sources (or sinks), which consist of local time change of total energy and divergence of total energy flux, are estimated both in the surface layer of the earth and in the atmosphere as residues of the respective energy balance equations over the northern hemisphere for all months.

The seasonal variation of the energy sources in the surface layer of the earth shows that extremely strong energy sinks are found in winter and very strong sources in summer both in the Northwest Pacific Ocean and the Northwest Atlantic Ocean. In the Tropical Oceans, there are stationary sources throughout the year, which fact suggests northward energy transport by ocean currents. Energy sources under the ground surface, which consist of the local time change of internal energy and the heat of fusion of ice or snow, have a much smaller amplitude of seasonal varition than that in the oceans. In the high latitudes, the sinks, which are considered to be caused by freezing of soil water, appear in winter and the sources, which are by fusion of ice or snow, appear in summer.

The seasonal variation of energy sources in the atmosphere, which means divergence of total energy flux by atmospheric motion, shows that strong sources are found in winter and sinks in summer both over the North Pacific Ocean and the North Atlatic Ocean. Over the Tropics there are very strong energy sources through the year. It is found that condensation heat energy mainly contributes to the seasonal variation of energy sources in the atmosphere.
\end{abstract}

\section{Introduction}

The purpose of the present investigation is an analysis and interpretation of the seasonal variation of energy sources (or sinks) in the surface layer of the earth and in the atmosphere. Various components of heat at the earth's surface such as net long wave radiation flux, solar radiation incident, sensible heat flux and latent heat for evaporation were globally estimated for all months by Budyko $(1956,1963)$. The sensible heat flux and evaporation over the oceans have been estimated for summer and winter by Jacob (1943). Each component of heat budget on the surface of the Arctic Ocean was computed for all months by Fletcher (1966). Many other investigators estimated these components in heat budget on the surface for some limited areas in some special season, but no one except Budyko (1963) has estimated them over the northern hemisphere for all twelve months. Therefore, we used Budyko's heat data in the present study to compute the energy sources in the surface layer of the northern hemisphere for twelve months.

Energy sources in the lithosphere consists of local time change of both the internal energy and the fusion heat of snow or ice. Seasonal variation of these energy sources was graphically described at some stations by several investigators, but have not yet been obtained for the globe. Energy sources in the hydrosphere consists of the local time change of total energy and the divergence of total energy flux by ocean currents. Seasonal variation of the local time change of heat, which is the so-called heat storage, was globally obtained by Gabites (1950), Fritz (1958), Pattullo (1957) and Rasool and Prabhakara (1965). Therefore, we could compute the seasonal variation of the divergence of heat by subtracting the amount of heat storage from the heat sources 
and also of northward heat transport by integrating the divergence. Sverdrup (1957), Albrecht (1960) and Emig (1967) have estimated the annual northward heat transports in the Pacific and Atlantic Oceans by the heat balance method. But we do not know of any other estimation of the seasonal variation of the transport in the oceans besides the present work.

Global heat budget in the atmosphere has been computed by Mintz (1955), London (1957), Davis (1963), Houghton (1964), Asakura and Katayama (1964), Katayama $(1966,1967)$ and so on. The computations by London and Houghton are for the annual heat budget, by Mintz for seasonal, and by others for some special months such as January, April, July and October. For each of the twelve months we computed the energy sources over the northern hemisphere to describe more realistic seasonal variation of them. Each component of the energy balance equation in the atmosphere except the sensible heat is estimated in the present work. For the sensible heat the estimation by Budyko (1963) is used.

\section{Energy balance equations in the surface layer and in the atmosphere}

Schematic illustration of the energy budget is shown in Fig. 1 for the surface layer of the earth and for the atmosphere. The surface layer consists of lithosphere or hydrosphere under the earth's surface.

Energy gain in the column of the surface layer consists of the incoming solar radiation absorbed by the earth's surface $S R^{*}$, energy loss in the column consists of the upward long wave radiation from the earth's surface $N L R^{*}$, the sensible heat flux from the earth's surface to the atmoshere $S H$, the latent heat for evaporation $L E$ and the energy outflow through the lateral surface of the column $E F^{*}$. Then we get the energy balance equation in the surface layer as follows:

$$
\begin{aligned}
& E S T^{*}=-E F^{*}+S R^{*}-N L R^{*} \\
& -S H-L E,
\end{aligned}
$$

where $E S T^{*}$ shows the time change of energy storage of the column and hereafter we will call it energy store increase in the surface layer for simplicity.

Energy gain in the atmospheric column consists of the solar radiation absorbed by the atmosphere the upward net long wave radiation

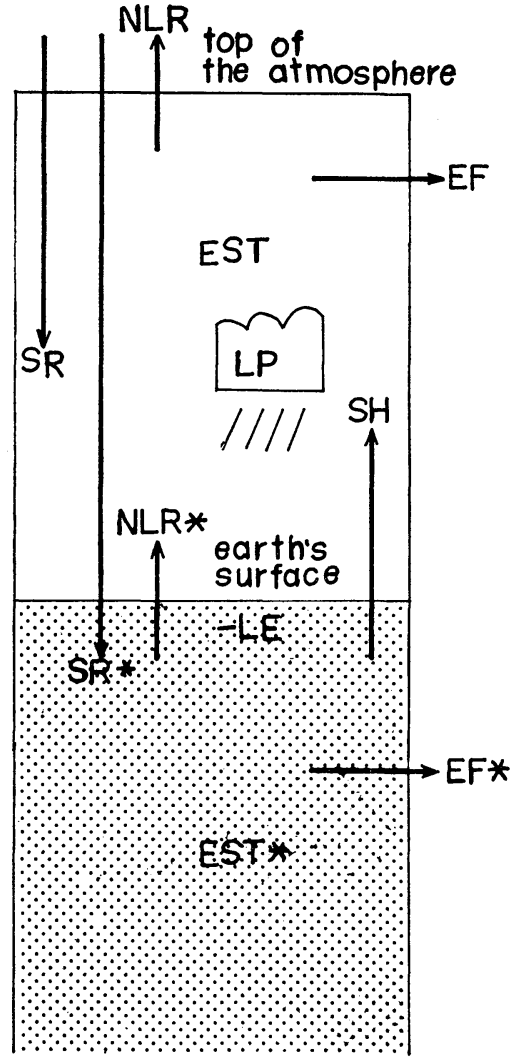

Fig. 1. Schematic illustration for energy budget below the earth's surface and in the atmosphere.

from the earth's surface to the atmosphere $N L R^{*}$ and the condensation heat released in the atmosphere LP. Energy loss in the atmospheric column consists of the net long wave radiation to the outer space from the top of the atmosphere $N L R$, and the energy outflow through the lateral surface of the column $E F$. Therefore we have the energy balance equation in the atmosphere:

$$
\begin{aligned}
& E S T=-E F+S R+N L R^{*}-N L R \\
& +S H+L P,
\end{aligned}
$$

where EST shows the time change of energy storage of the column, which we will call "energy store increase in the atmosphere" hereafter. By adding (1) and (2) we get the energy balance equation in the column throughout the earthatmosphere system.

$$
\begin{aligned}
& E S T^{*}+E S T=-E F^{*}-E F+S R^{*} \\
& +S R-N L R+L(P-E) .
\end{aligned}
$$

The energy store increase in the surface layer 
$E S T^{*}$ is represented by a function of the total energy included in the unit volume of the lithosphere or hydrosphere $W^{*}$ as follows:

$$
E S T^{*}=\partial\left[\overline{W^{*}}\right] / \partial t,
$$

where the brackets mean the integration for the surface layer of the earth within which the temperature changes seasonally and the bar denotes the monthly average. In the lithosphere, the total energy $W^{*}$ consists almost wholly of internal energy and fusion heat of snow or ice, that is,

$$
W^{*} \fallingdotseq \rho^{*} c_{1} T^{*}-m_{i} L_{i},
$$

where $\rho^{*}$ and $T^{*}$ are the density and the temperature of the earth's surface layer, $c_{1}$ is the specific heat of the lithosphere, $m_{i}$ the mass of snow or ice. As the rate of seasonal change of $\rho^{*}$ is one order of magnitude smaller than that of $T^{*}$, we have

$$
\begin{array}{r}
E S T^{*}=\rho^{*} c_{1} \partial\left[\bar{T}^{*}\right] / \partial t-L_{i} \partial\left[\bar{m}_{i}\right] / \partial t \\
\text { in the lithosphere. }
\end{array}
$$

In the hydrosphere, the total energy consists of internal energy, potential energy and kinetic energy, that is,

$$
W^{*}=\rho^{*} c_{h} T^{*}+\rho^{*} g z+\rho^{*} K,
$$

where $c_{h}$ the specific heat of the hydrosphere, $g$ the acceleration of the gravity and $-z$ the depth from the sea surface. However, the seasonal change of the kinetic energy is several orders of magnitude smaller than that of the internal energy in the hydrosphere. And when we assume that $\rho^{*}$ is constant, the potential energy has no seasonal change, and also

$$
\rho^{*} c_{h} \fallingdotseq 1 \mathrm{cal} \mathrm{deg}^{-1} \mathrm{~cm}^{-3} \text {. }
$$

Therefore we have the following approximation:

$$
\begin{aligned}
E S T^{*} \fallingdotseq \partial\left[\bar{T}^{*}\right] / \partial t \\
\text { in the hydrosphere. }
\end{aligned}
$$

The energy outflow through the lateral surface of the column of the lithosphere is near to zero:

$$
E F^{*} \fallingdotseq 0 \text { in the lithosphere. }
$$

The energy outflow through the lateral surface of the column of the hydrosphere consists of the divergence of total energy flux and the work done by the pressure force across the lateral surface of the column, that is,

$$
\begin{aligned}
E F^{*} & =\partial\left[\overline{\left(W^{*}+P\right) u}\right] / R \cos \varphi \partial \lambda \\
& +\partial \cos \varphi\left[\overline{\left(W^{*}+P\right) v}\right] / R \cos \varphi \partial \varphi
\end{aligned}
$$

$$
W^{*}=\rho^{*} c_{h} T^{*}+\rho^{*} g z+\rho^{*} K,
$$

where $P$ is the pressure, $R$ the earth's radius, $\varphi$ the latitude, $\lambda$ the longitude and $u$ and $v$ the east-west and north-south velocity component of sea currents, respectively. Under conditions of hydrostatic equilibrium the term in (11) involving pressure nearly cancels the term involving potential energy, so that the sum gives a negligible contribution (Jung (1952)). Using any reasonably assumed values for the magnitude of sea currents, it can be shown easily that the advection of the kinetic energy is several orders of magnitude smaller than the transport of internal energy (Jung (1952)). Thus if we use (8), we have the following approximation of the divergence of energy flux in the hydrosphere:

$$
\begin{aligned}
E F^{*} & \fallingdotseq \partial\left[\overline{T^{*} u}\right] / R \cos \varphi \partial \lambda \\
& +\partial \cos \varphi\left[\overline{T^{*} v}\right] / R \cos \varphi \partial \varphi .
\end{aligned}
$$

In conclusion the energy sources are approximately expressed in the lithosphere by summing (6) and (10) and in the hydrosphere by summing (9) and (13) as follows:

$$
\begin{gathered}
E S T^{*}+E F^{*} \fallingdotseq \rho^{*} c_{1} \partial\left[\overline{1^{*}}\right] / \partial t-L_{i}\left[\overline{m_{i}}\right] / \partial t \\
\text { in the lithosphere } \\
E S T^{*}+E F^{*} \fallingdotseq \partial\left[\overline{T^{*}}\right] / \partial t+\partial\left[\overline{T^{*} u}\right] / R \cos \varphi \partial \lambda \\
+\partial \cos \varphi\left[\overline{T^{*} v}\right] / R \cos \varphi \partial \varphi \\
\text { in the hydrosphere }
\end{gathered}
$$

These equations explain why the physical processes by which the energy sources are produced are different as between hydrosphere and lithosphere. This is one of the reasons why we discuss them both over the oceans and over the continents in the present study.

\section{Seasonal variation of the energy sources in the surface layer}

The energy sources are represented from (1) as follows:

$$
E S T^{*}+E F^{*}=\left(S R^{*}-N L R^{*}\right)-S H^{*}-L E .
$$

We estimated the monthly energy sources by (16) for each of the twelve months over the northern hemisphere. For the effective radiation $\left(S R^{*}\right.$ $\left.-N L R^{*}\right)$, the sensible heat flux $S H$ and the latent heat at the earth's surface $L E$, we used the climatic values estimated by Budyko (1963). Resultant distributions of the energy sources are shown in Fig. 2. The latitudinal distributions of zonally averaged energy sources are also given 

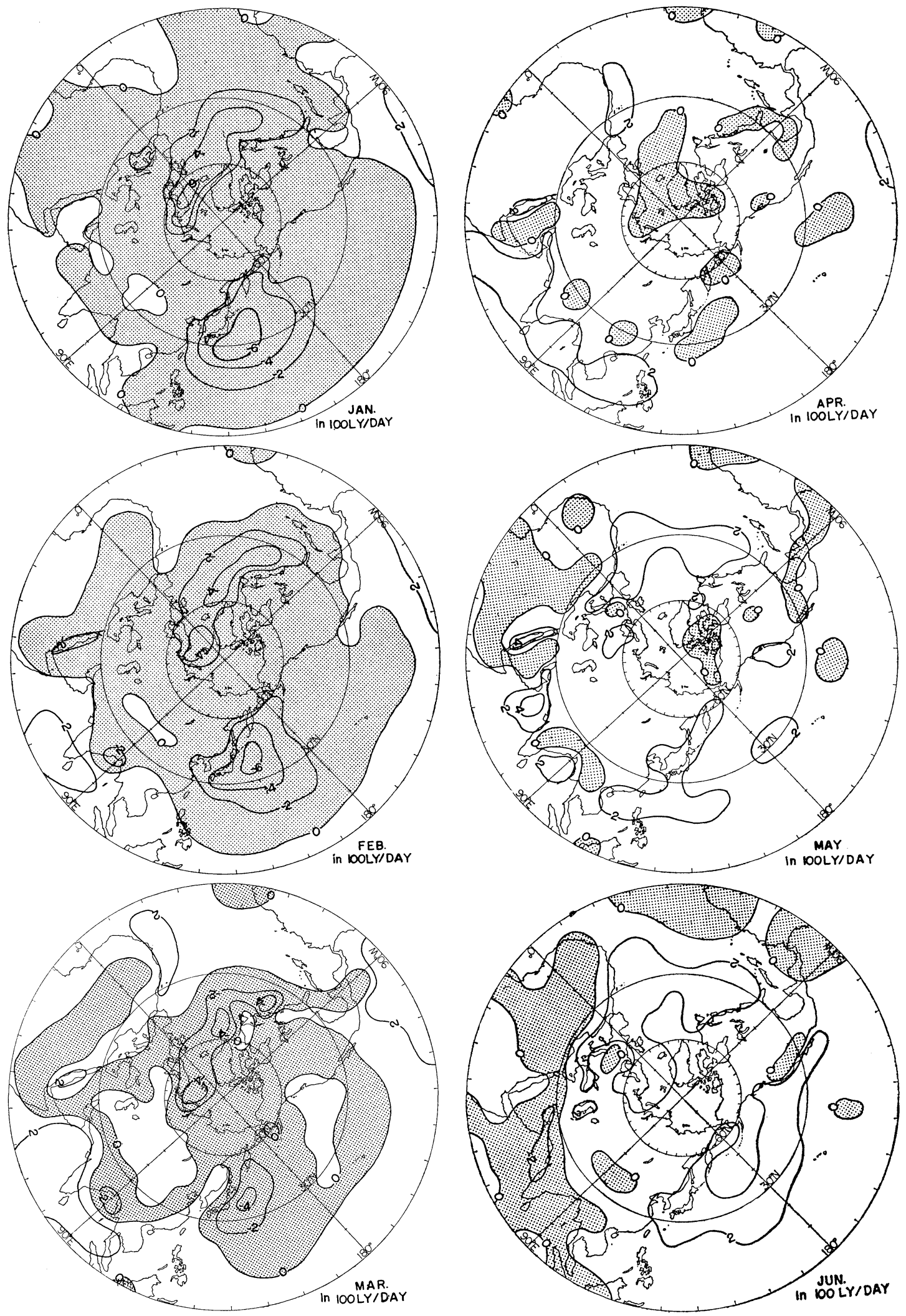

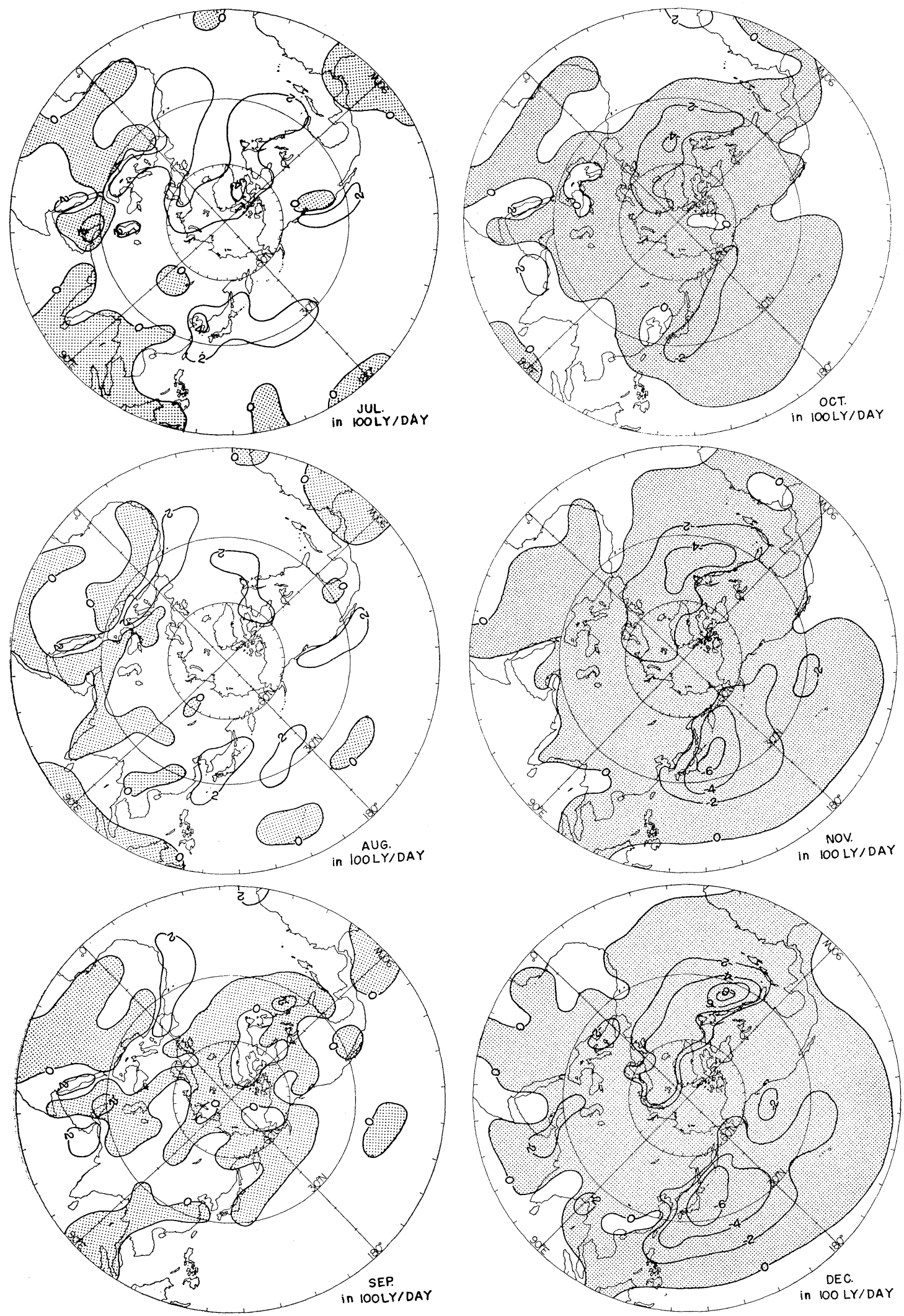
Fig. 2. Hemispheric distributions of the energy sources in the column of the earth surface layer $E S T^{*}+E F^{*}$.

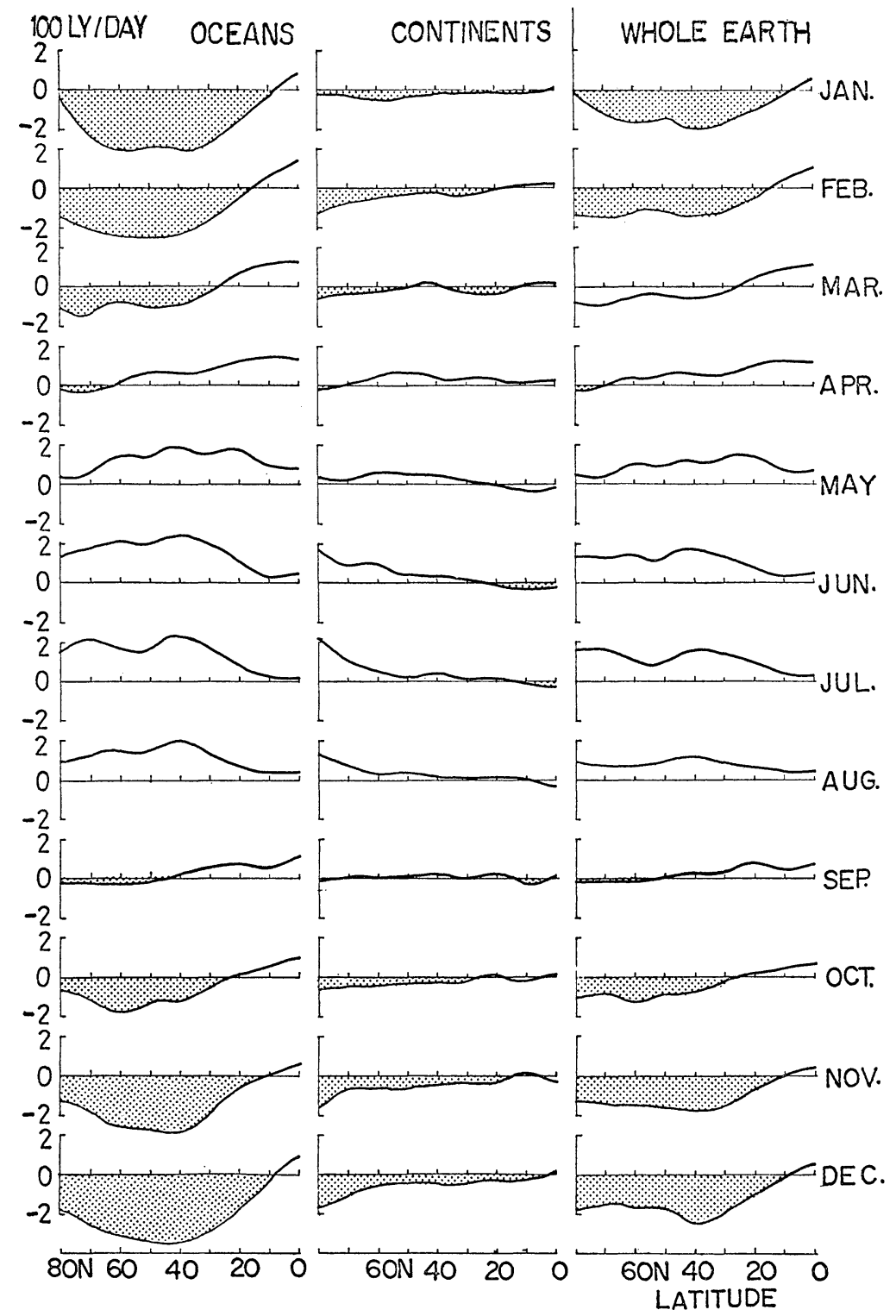

Fig. 3. Latitudinal distributions of zonally averaged energy sources $E S T^{*}+F E^{*}$ over the oceans, over the continents and over the whole latitude circle.

for oceans, continents and whole latitude circle respectively as in Fig. 3. From these figures we find the following features:

1) The most distinct point of the hemispheric distributions (Fig. 2) is that they have extremely strong sinks both over the North Pacific Ocean and the North Atlantic Ocean during winter half year. The centers of these sinks are located in the western areas of these Oceans. The minimum intensity of both sinks reaches to $-802 \mathrm{ly} \mathrm{day}^{-1}$ in December. These sinks in the Oceans in the winter half year turn to sources in the summer half year. The maximum intensity of both sources reaches to $409 \mathrm{ly} \mathrm{day}^{-1}$ in July.

2) The second feature of the distributions (Fig. 2) is that there are stationary sources in the 
tropics throughout the year. It is found that the sources are stronger in the tropical oceans than in the tropical lands. There are even very weak sinks in the tropical lands in some cases. This feature is shown very clearly in Fig. 3. These stationary energy sources in the tropical oceans cause northward transport of energy by the ocean currents.

3) The third feature of the distributions is that the seasonal variation of the sources in the continents is much smaller than that in the oceans (Fig. 2 and Fig. 3).

4) The fourth feature is that the sources in the continents show larger amplitudes in seasonal variation in the higher latitudes than in the lower latitudes (Fig. 3). In the high latitudinal area covered with snow or ice, it is expected that $-L i \partial[\bar{m} i] / \partial t$ has an important role in the construction of the energy sources during the season when snow melts. For example, we have $48 \mathrm{ly}^{\mathrm{day}}{ }^{-1}$ of zonally averaged sources along $50^{\circ} \mathrm{N}$ latitude in April. Normal snow depth at the ends of March and April are about $39 \mathrm{~cm}$ and $6 \mathrm{~cm}$, respectively (through these amounts are due to the estimation by Potter (1965) only for the Canadian area, they may well be considered to have generality). If a specific mass of snow is assumed to be 0.5 the snow mass melted in April is $17 \mathrm{gm} \mathrm{cm}^{-1}$. Fusion heat amount for it is $1360 \mathrm{ly} \mathrm{month}{ }^{-1}$, that is, $45 \mathrm{ly} \mathrm{day-1}$, because fusion heat is $79.7 \mathrm{cal} \mathrm{gm}^{-1}$. This fact seems to show that most of energy sources are originated from snow melting. For another example, along $70^{\circ} \mathrm{N}$ we have the zonally averaged heat sources of 131 ly day ${ }^{-1}$ in July and the zonally averaged heat sinks of $-85 \mathrm{ly} \mathrm{day}{ }^{-1}$ in December. We do not know which plays the main role in these sources and sinks, the local time change of internal energy or of fusion of ice. If the local time change of internal energy were zero $\left(\rho^{*} v_{1} \partial\left[\bar{T}^{*}\right] / \partial t \fallingdotseq 0\right), \quad$ an amount of melted ice of $1.6 \mathrm{gm} \mathrm{day}^{-1}$ is required to produce the heat source of $131 \mathrm{ly} \mathrm{day}^{-1}$ in July and an amount of frozen soil water of $1.1 \mathrm{gm} \mathrm{day}^{-1}$ is required to produce the heat sink of $-861 \mathrm{y}$ day $^{-1}$ in December.

\section{Estimation of zonally averaged heat divergence in the oceans and northward heat transport by ocean currents}

Seasonal variations of the heat store increase in the oceans, $\partial\left[\overline{T^{*}}\right] / \partial t$, were estimated by
Gabites (1950), Pattullo (1957), Fritz (1958) and Rasool and Prabhakara (1965). These estimations are all for zonally averaged ones. No one estimated the global distributions of them for every month. The brackets [ ] mean the vertical integration for the sea surface layer in which the temperature varies seasonally. To depict the seasonal variations of the heat store increase in the ocean, we need bathythermograph data of the sea surface layer for all seasons. However, the bathythermograph data are available for limited areas only. So, Gabites estimated the heat store increase in the oceans assuming a single linear empirical formula between the change in the mean monthly temperature of the sea surface and heat storage in the oceans through the year. This model consists of a layer from the surface to a depth of 25 metres, in which the temperature changes identical with the surface, and another layer beneath this in which the amplitude of temperature change decreases linearly to zero at a depth of 125 metres. Fritz estimated it assuming the same kind of linear empirical formulas as Gabites' but adopted different proportional coefficients for seasons. To decide these coefficients, he used the temperature of the layer from the surface to a depth of 300 feet. Rasool and Prabhakara estimated it using Fritz's method and new data of monthly sea surface temperature. In the present paper we quote Rasool and Prabhakara's estimation of the zonally averaged heat store increase in the oceans, $\partial<\left[\overline{T^{*}}\right]>/ \partial t$, where $<>$ means zonal average. Fig. 4 (upper) shows the heat store increase in the oceans as function of latitude and time of year. Quantities in this figure are weighted according to the proportion of the ocean area in each latitude, unlike Rasool and Prabhakara's figure.

1) In the extratropics, heat in the ocean is being stored in the summer half year, and released in the winter half year. The maximum energy release of $245 \mathrm{ly}$ day $^{-1}$ occurs at $30^{\circ} \mathrm{N}$ in January and the maximum energy storing of $180 \mathrm{ly} \mathrm{day}^{-1}$ occurs at $30^{\circ} \mathrm{N}$ in July.

2) In the tropics, the heat storage has two weak maximums, one in spring and the other in autumn, and two weak minimums, one in sumrer and the other in winter.

3) As shown in the right-hand part of Fig. 4 (upper), the annual value of $\partial<\left[T^{*}\right] / \partial t$ is zero.

Averaging (15) zonally, we have $<E S T^{*}+E F^{*}>=\partial<\left[\overline{T^{*}}\right]>/ \partial t$ 

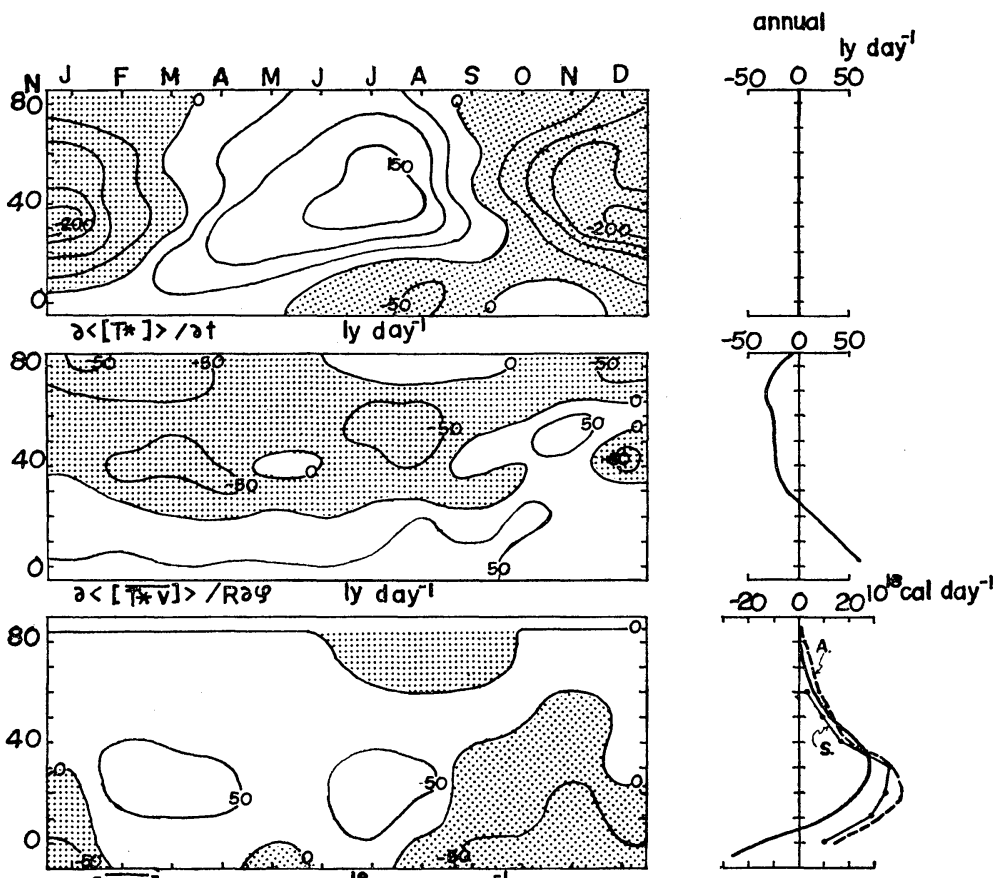

Fig. 4. Latitudinal distributions of zonal heat store increase in the oceans, $\partial<[\overline{T *}]>/ \partial t$, in ly day ${ }^{-1}$ after Rasool \& Prabhakara (upper), zonally averaged divergence of heat flux in the oceans, $\partial<\left[\overline{T^{*} v}\right]>$ $/ R \partial \varphi$, in ly day ${ }^{-1}$ (middle), and northward heat transport by the ocean currents, $\left\langle\left[\overline{T^{*} v}\right]\right\rangle$, in $10^{18} \mathrm{cal} \mathrm{day}^{-1}$. In the right-hand part, the dotted and broken lines show Sverdrup's (1957) and Albrecht's (1960) estimations, respectively.

$$
+\partial<\left[\overline{T^{*} v}\right]>/ R \partial \varphi
$$

where $<>=(1 / R \cos \varphi) \oint R \cos \varphi \partial \lambda$.

As the components: $\left\langle\mathrm{EST} T^{*}+E F^{*}\right\rangle$ and $\partial<\left[\overline{T^{*}}\right]>/ \partial t$ in (17) are already known, we can calculate the component $\partial<\left[\overline{T^{*} v}\right]>/ R \partial \varphi$ from (17). This term represents divergence of heat flux by ocean currents, which is given in Fig. 4 (middle) as a function of latitude and time of year.

1) For most of the year the oceans south of $30^{\circ} \mathrm{N}$ have heat sources and the oceans north of $30^{\circ} \mathrm{N}$ have heat sinks except in autumn, when the sources are found at $50^{\circ} \mathrm{N}$. The minimum value of the sinks is -88 ly day ${ }^{-1}$ at $50^{\circ} \mathrm{N}$ in July, and the maximum of the sources is $98 \mathrm{ly}$ day $^{-1}$ at the Equator in August.

2) The amplitude of the seasonal variation of $\partial<\left[\overline{T^{*} v}>/ R \partial \varphi\right.$ is much smaller than that of $\partial<\left[\overline{T^{*}}\right]>/ \partial t$.

3) The latitudinal distribution of the annual value of $\partial\left\langle\left[\overline{T^{*} v}\right]>/ R \partial \varphi\right.$ which is shown in the right-hand part of Fig. 4 (middle), shows that it has a heat source south of $28^{\circ} \mathrm{N}$ and a heat sink north of $28^{\circ} \mathrm{N}$.

Integrating $\partial<\left[\overline{T^{*} v}\right]>/ R \partial \varphi$ with respect to $R d \varphi$ and employing $\left\langle\left[\bar{T}^{*} v\right]\right\rangle \fallingdotseq 0$ at $85^{\circ} \mathrm{N}$, we have the value of $\left\langle\left[\overline{T^{*} v}\right]\right\rangle$ which represents the northward heat transport by ocean currents. It is given in Fig. 4 (lower), as a function of latitude and time of year.

A prominent feature of transport in the lower latitudes is the southward heat transport, in autumn and winter. The maximum intensity of the transport is $-89 \times 10^{-18} \mathrm{cal} \mathrm{day}^{-1}$ at $5^{\circ} \mathrm{S}$ in November. In spring and summer, we have an intense northward transport over the whole latitudes in the northern hemisphere. The maximum transport is $82 \times 10^{18} \mathrm{cal} \mathrm{day}^{-1}$ at $25^{\circ} \mathrm{N}$ in July. In the right-hand part of Fig. 4 (lower), the latitudinal distribution of annual northward heat transport $\left\langle\left[T^{*} v\right]\right\rangle$ (solid line) is shown together with that estimated by Sverdrup (1957) 
(dots) and by Albrecht (1960) (broken line). There is fair agreement in the northern portion, but considerable difference between Budyko's on the one hand and Sverdrup's and Albrecht's on the other, in the heat transport in the Tropics.

If we take the annual mean of the equations (14) and (15), the local time change of $T^{*}$ or $W^{*}$ becomes zero and we have

$$
\begin{aligned}
& E S T^{*}+E F^{*} \fallingdotseq \\
& \left\{\begin{array}{r}
-L i \partial[\overline{m i}] / \partial t \quad \text { in the lithosphere } \\
\partial\left[\overline{T^{*} u}\right] / R \cos \partial \lambda+\partial \cos \varphi\left[\overline{T^{*} v}\right] / R \cos \varphi \partial \varphi \\
\text { in the hydrosphere, }
\end{array}\right.
\end{aligned}
$$

where the heavy bar - means annual average and ${ }^{\prime \prime}$ means the annual average of fusion heat used for the melting of snow on the ground surface. The heat released in snow formation is given out to the atmosphere and does not affect the heat balance in the lithosphere. The annual total of fusion heat for ice on the sea or in the soil becomes zero because we assume no yearly change of climatic quantities. Then, we do not need to consider the effect of fusion heat for ice on the annual heat balance in the lithosphere or in the hydrosphere. The annual energy sources computed after the right-hand side of (18) is given in Fig. 5.

1) There are two intensive sinks owing to energy convergence by ocean currents over the

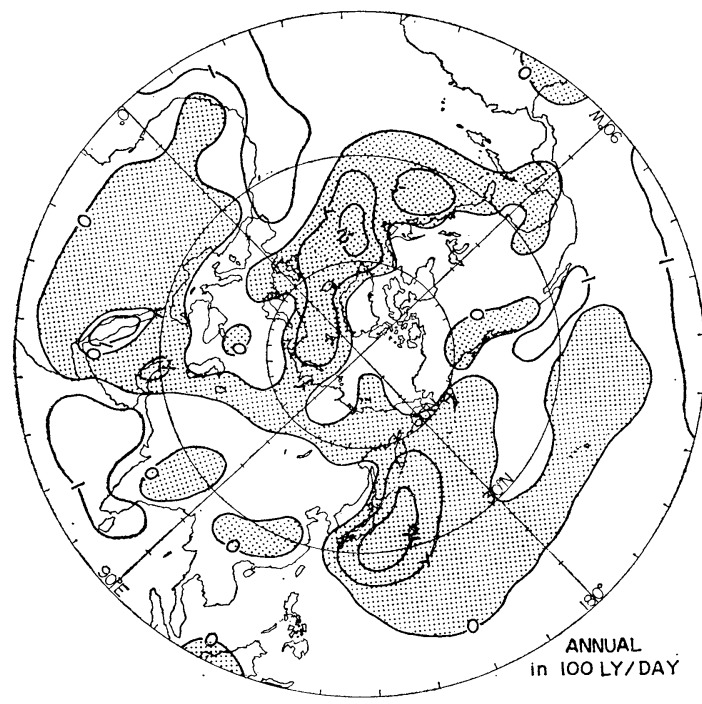

Fig. 5, Hemispheric distribution of annual energy sources in the earth surface layer, $\left[\overline{T^{*} u}\right] / R \cos \varphi \partial \lambda+\partial \cos \varphi\left[\overline{T^{*} v}\right] / R \cos \varphi \partial \varphi$, in $1 \mathrm{y}$ day $^{-1}$.
Northwest Pacific and North Atlantic Ocean. The minimum value of these sinks reaches -266 ly day $^{-1}$ over the Pacific Ocean northeast of Japan.

2) Heat sources due to divergence by ocean currents are found over the equatorial oceans off the west coast of North America and the west coast of Africa.

3) We have a strong heat source over the Indian Ocean. It is presumable that the heat diverges to the South Indian Ocean by the ocean currents.

\section{Estimation of monthly averaged energy sources in the atmosphere}

The monthly energy store increases in the atmosphere $E S T$ is represented as follows:

$$
E S T=\partial\left\{\overline{\rho\left(c_{v} T+g z+K\right)}\right\} / \partial t=\partial\left\{\overline{\rho\left(c_{p} T+K\right)}\right\} / \partial t
$$

where $\rho$ denotes the air density, $c_{v}$ the specific heat at constant volume, $c_{p}$ the specific heat at constant pressure, $T$ the air temperature and $K$ the kinetic energy. The brackets mean

$$
\{\}=(1 / g) \int_{0}^{p_{s}} d p,
$$

where $p_{s}$ denotes the surface pressure. The monthly divergence of energy flux with work done by pressure force across the lateral surface of the column in the atmosphere is represented as follows:

$$
E F=\partial\left\{\overline{W^{\prime} u}\right\} / R \cos \varphi \partial \lambda+\partial \cos \varphi\left\{\overline{W^{\prime} v}\right\} / R \cos \varphi \partial \varphi
$$

Here, $W^{\prime}=\rho\left(c_{p} T+g z+K\right)$ or $\rho\left(R^{\prime}+c_{p}\right) T+\rho K$,

where $R^{\prime}$ denotes the gas constant.

Summing (19) and (21), we have the so-called energy sources in the atmosphere as follows:

$$
\begin{aligned}
E S T & +E F=\partial\left\{\overline{\rho\left(c_{p} T+K\right)}\right\} / \partial t+\partial\left\{\overline{W^{\prime} u}\right\} R \cos \varphi \partial \lambda \\
& +\partial \cos \varphi\left\{\bar{W}^{\prime} v\right\} / R \cos \varphi \partial \varphi
\end{aligned}
$$

On the other hand, the energy source is represented from (2) as follows:

$$
E S T+E F=S R+\left(N L R^{*}-N L R\right)+S H+L P
$$

We computed the energy sources by giving the normal monthly values of each term in the righthand side of (24).

The solar radiation absorbed by the atmosphere, 
$S R$, in the right-hand side of (24) was computed, using the following formula deduced by Adem (1962):

$$
S R=(0.30-0.26 n) I
$$

where $n$ is the cloud amount, $I$ the incident solar radiation at the outer boundary of the atmosphere. Data for $n$ are after Budyko (1963) and those over latitudes higher than $65^{\circ} \mathrm{N}$ after the U.S. Navy (1965).

Katayama (1967) obtained a useful empirical formula for the cooling rate of the tropospheric column without cloud:

$$
\left(N L R^{*}-N L R\right)^{\circ}(\mathrm{ly} / \text { day })=404+6.67 t
$$

where $t$ means temperature in ${ }^{\circ} \mathrm{C}$ at $500 \mathrm{mb}$ level. The contribution of cloud cover to $\left(N L R^{*}-N L R\right)$ varies exactly with cloud types (especially with cloud height). The relationship between total cloud amount and $N L R^{*}-N L R$ is indefinite (Katayama, 1967). Therefore we dared to assume the following equation to compute the cooling rate of the atmospheric column:

$$
N L R^{*}-N L R=404+6.67 t
$$

Data $t$ are based on $500 \mathrm{mb}$ level temperature distributions over the northern hemisphere in The Chief of Naval Operations (1966). The stations covered are about 520 in number over the northern hemisphere and the data are averages for 1960-1964.

The sensible heat $S H$ is read at every 10 degrees' intersection of longitude and latitude from the Atlas by Budyko 1963. Climatic monthly precipitation is based on WMO (1962) and Hatakeyama, ed. (1964). The period covered in WMO (1962) is $1931-1960,1941-1960$ or 1951 1960. As precipitation data over People's Republic of China, Democratic People's Republic of Korea, Republic of Turkey, People's Republic of Mongol, Republic of Indonesia, Kingdom of Saudi Arabia are wanting in WMO (1962), they are obtained from Hatakeyama (1964). The periods for which averages are presented are various. The data of about 814 stations in all were plotted over the northern hemisphere.

\section{Seasonal variation of energy sources in the atmosphere}

The hemispheric distributions of the climatic monthly energy sources in the atmosphere are given for every months of the year in Fig. 6.
Latitudinal distributions of zonally averaged energy sources over oceans, over continents and over whole latitude circle are given for each month in Fig. 7.

1) In winter, there are sources in the atmosphere both over the North Pacific and the North Atlantic Ocean (Fig. 6) because the sensible heat flux from the underlying warmer sea surface to the colder atmosphere is strong and also precipitation is heavy over these areas. The maximum value of the sources reaches to $395 \mathrm{ly} \mathrm{day}^{-1}$ off the east coast of Japan in January. On the contrary, energy sinks below the sea surface are very strong in these areas in winter owing to the heat expense of the sensible heat flux and evaporation as shown in Fig. 2.

During the summer half-year, there are strong sinks in the atmosphere over these areas. The minimum of the sinks is -222 ly day $^{-1}$ over the North Pacific Ocean in June. On the contrary, there are strong energy sources below both oceans during the summer half-year as shown in Fig. 2.

2) Strong sources in the atmosphere, which are formed mainly by the heavy rain, are found in the Tropics during the whole year. They are especially strong over the Eastern Indian Ocean, the Western Pacific Ocean, South America and Western Africa.

Condensation heat release in the summer monsoon over southeast Asia produces the strongest source of $830 \mathrm{ly} \mathrm{day}^{-1}$ in August over the northern hemisphere.

3) The Arctic Circle is occupied by a stationary energy sink for all months. The cooling rate of the atmosphere by the radiation balance (NLR $\left.-N L R^{*}\right)-S R$ is stronger in the lower latitudes than in the higher. The latitudinal distributions of the sensible heat flux do not contribute so much to those of the atmospheric energy sources as the condensation heat release. The latitudinal gradient of the condensation heat amount is so steep that the atmospheric energy sources have almost the same latitudinal gradient as the condensation heat component.

4) By comparison of the distributions of averaged total energy sources in Fig. 6 with the distributions of monthly condensation heat, we comprehend that the monthly condensation heat energy plays a main role in the monthly total energy sources. Correlation coefficients between the two components at every 10 degrees' 

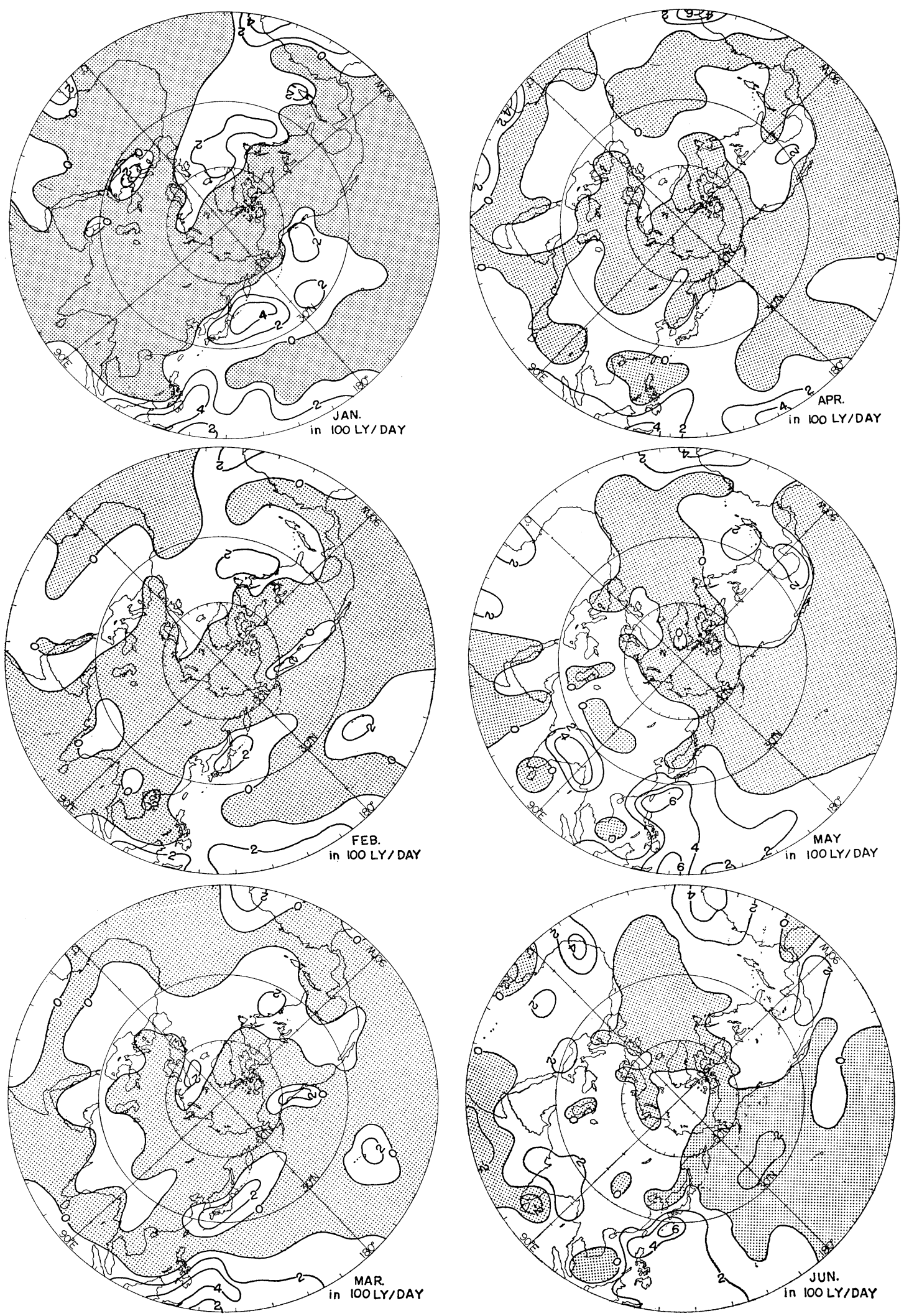

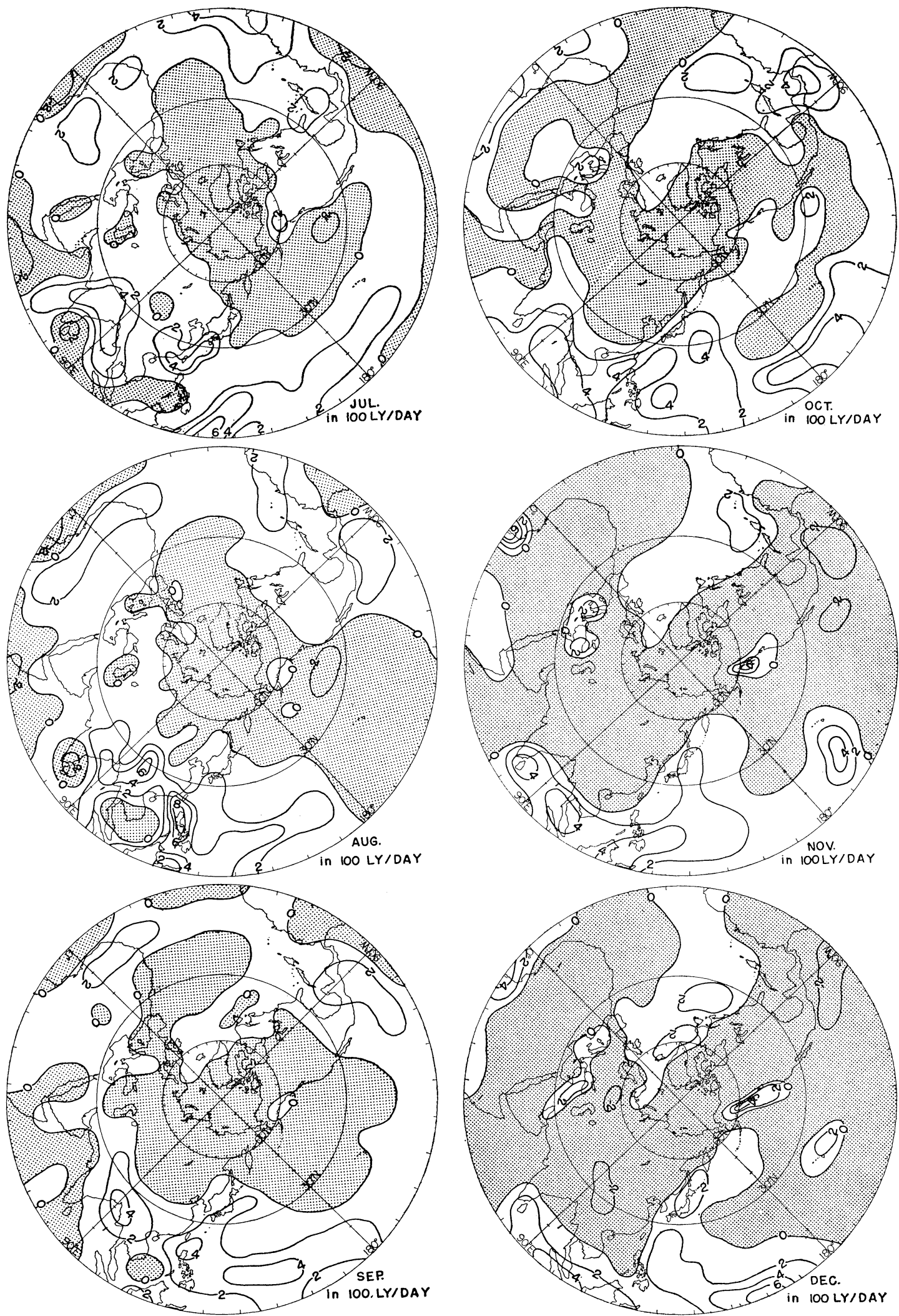
Fig. 6. Hemispheric distributions of monthly energy sources in the atmosphere, $E S T+E F$, in ly day ${ }^{-1}$.

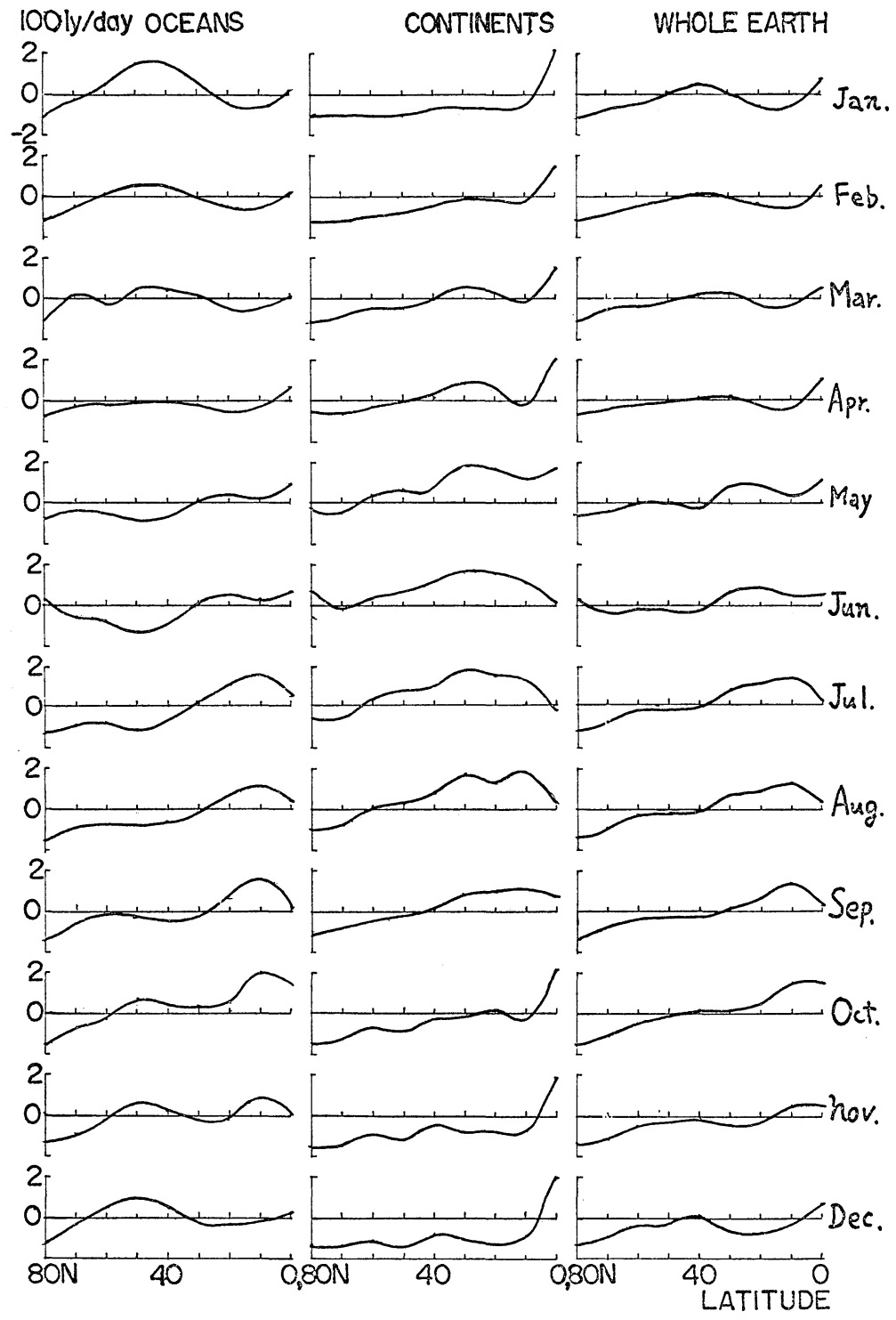

Fig. 7. Latitudinal distributions of zonally averaged energy sources, $E S T+E F$, over the oceans, over the continents and over the whole latitude circle.

intersection of longitude and latitude over the over the Equatorial continents in the winter northern hemisphere are shown in Table 1. half-year. In the summer half year the location These high correlation coefficients for all months of the maximum source is displaced northward to go to show the great role that the condensation near $30^{\circ} \mathrm{N}$. The feature of seasonal variation is heat component plays in the distribution of the also seen in the case of zonally averged precipitatotal energy sources.

tion. It is certain that precipitation plays a very

5) In Fig. 7, extremely strong sources are found important role in the distribution of energy 
Table 1. Correlation coefficients between total energy sources in the atmosphere $E S T+E F$ and condensation heat release $L P$

\begin{tabular}{lccccccccccc}
\hline month & 1 & 2 & 3 & 4 & 5 & 6 & 7 & 8 & 9 & 10 & 12 \\
\hline corr. & 0.90 & 0.80 & 0.83 & 0.82 & 0.83 & 0.74 & 0.82 & 0.85 & 0.90 & 0.95 & 0.92
\end{tabular}

sources.

Gabites (1950) estimated the zonally averaged energy store increase EST and the energy divergence $E F$ in the atmophere at every 10 degrees of latitude for every month. The amplitude of annual variation of $E S T$ is much smaller than that of $E F$. Therefore we assume that EST is negligible compared with $E F$. Zonally averaging and integrating (24) with respect to $R d \varphi$ from the North Pole to the latitude $\varphi$ and using (21), we get the following zonally averaged northward transport:

$$
\begin{aligned}
& <\left\{\overline{\rho\left(c_{p} T+g z+K\right) v}\right\}>=\int_{N . P .}^{\varphi}<S R \\
& +\left(N L R^{*}-N L R\right)+S H+L P>R d \varphi
\end{aligned}
$$

because $(c p T+g z+K) v=0$ at the North Pole, where $\langle>=\oint R \cos \varphi d \lambda$. Latitudinal distributions of $\left\langle\left\{\overline{\rho\left(c_{p} T+g z+K\right) v}\right\}\right\rangle$ computed by (28) are shown for all months in Fig. 8.

In the winter half year, $\left\langle\left\{\overline{\rho\left(c_{p} T+g z+K\right) v}\right\}>\right.$ shows that the energy is on the whole transported northward over each latitude and have two maximums i.e. in the Tropics and in middle latitudes. In the summer half-year, it is shown that the energy is transported southward in low latitudes and northward in high latitudes. The northward transport reaches the maximum of 99 cal day ${ }^{-1}$ at $5^{\circ} \mathrm{N}$ on December and the southward transport the maximum of $187 \mathrm{cal} \mathrm{day}^{-1}$ at $5^{\circ} \mathrm{S}$ in July. Let us compare the latitudinal and seasonal distributions of the energy transport by the atmosphere (Fig. 8) with those by the oceans (Fig. 4 lower). In the first place, it is to be noticed that the values of both transports are comparable. But the maximums of northward and southward transports by the atmosphere are respectively larger than the maximums of those by the oceans.

Mintz (1955) directly estimated the seasonal energy transport for 1949 by atmospheric disturbances occurring north of $20^{\circ} \mathrm{N}$. In the right-hand part of Fig. 8, we can compare our computation with Mintz's result in summer and in winter. They are coincident except in winter in the vicinity of $50^{\circ} \mathrm{N}$ where our value is smaller than Mintz's. They have this feature in common that the latitudinal distribution of energy transport has two maximums, i. e. at $50^{\circ} \mathrm{N}$ and in the Tropics, in winter.

\section{Summary and suggestions for future work}

Energy sources both in the surface layer and in the atmosphere were estimated over the northern hemisphere for each of the twelve months, Seasonal variations of these sources were discussed by comparisons between the surface layer and the atmosphere and between over oceans and over continents. The following features were

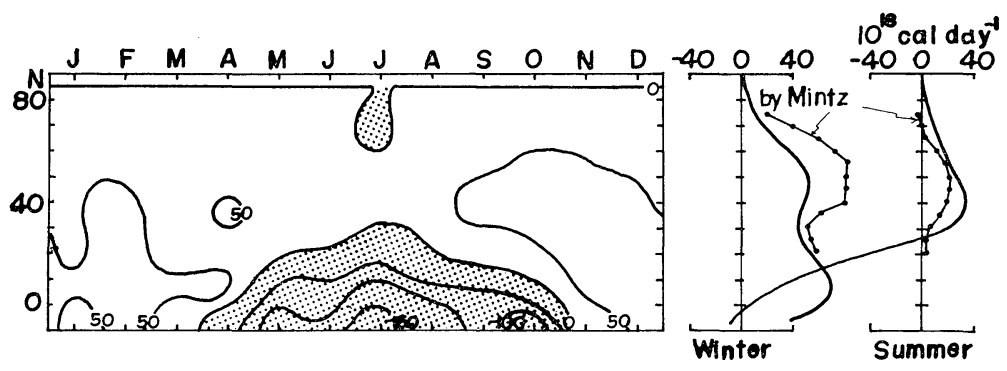

Fig. 8. Latitudinal distributions of the northward energy transport by the atmospheric disturbances, $\left\langle\left\{\overline{\rho\left(c_{p} T+g z+K\right) v}\right\}>\right.$, in cal day ${ }^{-1}$. Solid curves in the right-hand part show the seasonal averaged northward energy transport after the present computation and dots show that after direct computation for 1949 by Mintz (1955) for winter (Jan. and Feb.) and for summer (Jul. and Aug.). 
found:

Seasonal variations of energy sources in the hydrosphere have much larger amplitudes than those in the lithosphere, those in the northern parts of the oceans being particularly large. Energy sources in the lithosphere are near to zero throughout the year. The weak seasonal variation in the high latitudinal lithosphere is presumed to be caused by the phase change of soil water. In the atmosphere, seasonal variations of energy sources are not so different between over oceans and over continents unlike in the surface layer. Over the northern parts of both the Oceans, sinks appear in winter and sources in summer, contrary to the circumstances in those parts. Condensation heat amount plays a predominant role in the seasonal variation of energy sources in the atmosphere. Seasonal variation of northward transport of energy by the ocean currents is comparable with that by the atmospheric disturbances.

It is an interesting problem for us to estimate the distributions of the energy store increase in the northern hemispheric oceans for each of the twelve months. This gives us the estimation of the distributions of the transportation of the energy in the oceans for all months also.

We may be able to express each term of two energy budget equations for the surface layer and for the atmosphere by functions of temperatures of $t \mathrm{e}$ earth's surface and the mid-troposphere and the incident at outer atmopsheric solar radiation. That is interesting to us, because, if we can do, we have a closed system of energy budget equations and then can express the seasonal variations of temperatures of the earth's surface and of the mid-troposphere by that of the incident outer atmospheric solar radiation.

Gabites (1950) gave a good approximation of the energy store increase in the oceans by a linear formula of time change of surface temperature. It was found in the present study that the divergence of energy flux in the atmosphere depends much on the condensation heat release in the atmosphere. Saltzman (1967), in his theory of climate, expressed the sensible heat and the evaporation at the earth's surface by a proportion of temperature difference of the earth's surface and the mid-troposphere, expressed the net long-wave radiation flux at the earth's surface and at the top of the atmosphere by functions contained temperature of the earth's surface and of the mid-troposphere and also expressed the incident solar radiation absorbed by the earth's surface and the atmosphere by functions of the outer atmospheric solar radiation. When we have expressed the other terms of the energy bydget equations by functions of these temperatures and solar radiation, we may reasonably expect some good results.

\section{Acknowledgements}

The author wishes to express his gratitude to Dr. Hiroshi Ito, the Meteorological Agency, and Dr. Akira Katayama, the Meteorological Research Institute, for their effective advice.

\section{References}

Adem, J., 1962: On the theory of the general circula tion of the atmosphere. Tellus, 16,102-115.

- 1964: On the normal thermal state of the troposhere ocean-continent system in the northern hemisphere. Geofisica internacional, 4, 3-32.

, 1964: On the physical basis for the numerical prediction of monthly and seasonal temperatures in the troposphere ocean-continent system. Mon. Wea. Rev., 92, 91-102.

, 1965: Experiments aiming at monthly and seasonal numerical weather prediction. Mon. Wea. Rev., 93, 495-502.

Albrecht, F., 1960: Jahreskarten des Wärme- und Wasserhaushaltes der Ozeane. Ber. deut. Wetterdienstes, 66, Bd. 9, 19.

Aldoshina, E.I., 1957: Teplovoì balans poverkhnosti yaponskogo morya. Trydy Gosudarstvennog okeanograficheskogo Institut, Vȳpusk 35, 119-159.

Aldoshina, E.I., 1961: Vodnȳī i teplovoì balans yaponskogo morya. Osnovnȳe Chertȳ Geologii i Gidrologii Yaponskogo Morya. Izdatelistvo Akademii Nauk SSSR, Moskva, 132-145.

Arakawa, A., 1958: Recent theories of general circulation. (in Japanese) Kisho Kenkyu Note, 9, 4, 1-134.

Asakura, T., and A. Katayama 1964: On the normal distribution of heat sources and sinks in the lower troposphere over the northern hemisphere. $J$. meteor. Soc. Japan, 42, 209-244.

Ashburn, E.V., 1963: The radiation heat budget at the ocean-atmosphere interface. Deep Sea Research, 10, 5, 597-606.

Bryan, K., 1962: Measurements of meridional heat transport by ocean currents. J. of Geophs. Res. 67, 3403-3414.

Budyko, M.I., 1956: Teplovoi balans zemnoi poverkhnosti (The heat balance of the earth's surface). Hydrometeorological Publishing House, Leningrad, 254pp. (translated into English by N.A. Stephanova, U.S. 
Weather Bureau, 1958)

Chief of Naval Operations, 1966:, Selected level temperatures and dew points for the northern hemisphere. NAVAIR 50-IC-52, 259pp.

Davis, P.A., 1963: An analysis of the atmospheric heat budget. J. Atmos. Sci., 20, 5-22.

Emig, M., 1967: Heat transport by ocean current. $J$. of Geophys. Res., 72, 2519-2529.

Fletcher, J.O. Edt. 1966: Proceedings of the symposium on the arctic heat budget and atmospheric circulation. U.C.L.A. and the Rand Corporation, 342pp.

Fritz, S., 1958: Seasonal heat storage in the ocean and heating of the atmosphere. Arch. Meteor. Geophys. Bioklimatol., A, 10(4), 291-300.

Gabites, J.F., 1950: Seasonal variation in the atmospheric heat balance. Sc. D. Thesis, M.I.T. Cambridge, $147 \mathrm{pp}$.

Gavrilin, B.L., 1965: Numerical experiments on the general circulation of the atmosphere. Izv. Atmospheric and Oceanic Physics Series, 1, 1229. 1259 (translated by Allen B. Kaufman).

Hatakeyama, H. ed., 1964: Climate of Asia. Kokon Shoin, $577 \mathrm{pp}$.

Holopainen, E.O., 1965: On the role of mean meridional circulations in the energy balance of the atmosphere. Tellus, 17, 285-294.

Houghton, H.G., 1954: On the annual heat balance of the northern hemisphere. J. Meteor., 11, 1-9.

Jacob, W.C., 1943: Sources of atmospheric sources and moisture over the North Pacific and North Atlantic Oceans. Ann. N.Y. Acad. Sci., 44, 19-40.

Japan Meteorological Agency, 1959: Chijo Kisho Joyo Hyo. $144 \mathrm{pp}$.

Japan Meteorological Association, 1963: Monthly mean surface temperature anomaly charts for the northern hemisphere.

Jung, G.H., 1952: Note on the meridional transport of energy by the oceans. J. Marine Research, Sears Foundation, 11, 2,139-146.

Katayama, A., 1966: On the radiation budget of the troposphere over the northern hemisphere (1). $J$. Meteor. Soc. Japan, 44, 381-401.

- 1967: On the radiation budget of the troposphere over the northern hemisphere (2), (3). J. Meteor. Soc. Japan, 45, 1-39.

Manabe, S., and F. Möller, 1961: On the radiative equilibrium and heat balance of the atmosphere. Mon. Wea. Rev., 89, 503-532., and R.S. Strickler, 1964: Thermal equilibrium of the atmosphere with a convective adjustment. J. Atm. Sci. , 21, 361-385.,

, J. Smagorinsky and R.F. Strichler, 1965: Simulated climatology of general circulation with a hydrologic cycle. Mon. Wea. Rev., 93, 769-798.,

, and R.J. Wetherald, 1967: Thermal equilibrium of the atmosphere with a given distribution of relative humidity. J. Atm. Sci., 24, 241-259.

Mintz, Y., 1955: The total energy budget of the atmosphere. Final Rep., Gen. Circ. Proj., Confr. AF19 (122)-48, Dept. Meteor., Univ. California, Los Angeles, 8, 1-6.

Mitchell, J.M., Jr., 1965: Theoretical paleoclimatology. The Quaternary of the United States - A Review Volume for the Seventh Congress of the International Association for (Quaternary Research 901pp.), 881-901.

Palmén, E., 1966: On the mechanism of the vertical heat flux and generation of kinetic energy in the atmosphere. Tellus, 18, 835-845.

Pattullo, J.G., 1957: The seasonal heat budget of the oceans. Ph. D. Thesis, Univ. California, Los Angeles, $104 \mathrm{pp}$.

Peixoto, J.P., 1965: On the role of water vapor in the energetics of the general circulation of the atmosphere. Portugalae Physica, 4, 135-170.

Potter, J.G., 1965: Snow cover. Climatological Studies (Dep. of Transport Meteorological Branch, Canada, 69pp.)

Rasool, S.I., and C. Prabhakara 1966: Heat budget of the southern hemisphere. Problems of atmospheric circulation, Spartan Books, Washington, D.C.

Riehl, H., and J.S. Malkus, 1958: On the heat balance in the equatorial trough zone. Geophysica, 6, 503-537.

Saltzman, B., 1967: On the theory of the mean temperature of the earth's surface. Tellus, 19, 219-229.

Sverdrup, H.U., 1957: Oceanography. Handbuch der Physik, 48, Springer-Verlag, Berlin.

Tokyo Astronomical Observatory, 1958: Rika nenpyo 1958. Maruzen.

U.S. Navy, 1963: Marine climatic atlas of the world, 6 Arctic ocean. NAVWEPS 50-1c-533.

WMO, 1962: Climatological normals for the climate and climatic ship stations for the period 1931-1960 (CLINO). No. 117. Tp. 52.

Yamamoto, G., 1964: On atmospheric radiation. J. of the S.H.A.S.E., 38, 4, 229-247. 


\section{北半球の地・水圈と気圈におけるエネルギー源の季節変化}

\section{久保田効}

気象庁

気候的な熱・冷源つまり総エネルギーの局所時間変化十発散量が地・水圈と気圏それぞれのェネルギー・バラン ス方程式の残留項として計算される。 それらの毎月の北半球分布が与兄られ，季節变化が論じられる．水圈における 熱冷源分布では, 北西太凷洋と太西洋に, 冬極度に強い冷源が夏非常に強い熱源が現われる。熱帯の海洋には年間定 常な熱源が現われ，海洋によるェネルギーの北向き輸送を示唆している．地圈の熱・冷源分布は，内部エネルギーと 雪氷の融解熱の局所時間変化を意味するが, 水圈の熱冷源の季節変化に比べると, その变化は小さい。 しかし, 高緯 度では冬冷源・夏熱源を示しているのが判り, 夏の熱源は雪氷の融解熱に起因すること大であることが示唆される。 気圈の冷熱源分布では, 北太平洋と北太西洋上で冬強い熱源, 夏冷源, 熱帯では年中強い熱源を示している. 気圈の 冷・熱源の形成には, 凝結熱が重要な役割りを果すことが示される. 